\title{
RELATIONSHIP BETWEEN PROACTIVE COPING AND SELF-CARE MANAGEMENT IN PATIENT WITH PULMONARY TUBERCULOSIS
}

\author{
Tintin Sukartini, Febrina Ramadhani, Laily Hidayati \\ Faculty of Nursing, Universitas Airlangga \\ Kampus C Mulyorejo Surabaya, 60115, Phone. (031)5913752, Fax. (031)5913257 \\ E-mail: tintin-s@fkp.unair.ac.id
}

\begin{abstract}
Introduction: Patients with pulmonary tuberculosis not only experience physical problems but also face psychosocial problems, and this can get worse during the treatment phase that has an impact on the patients' self-care. In order to prevent further impact on the patients, proactive coping is needed. This study aimed to identify the relationship between proactive coping and self-care management in pulmonary tuberculosis patients. Methods: This study was a cross-sectional research study. As many as 105 respondents were taken with a consecutive sampling technique. The inclusion criteria of the respondents were that they were pulmonary tuberculosis patients both in the intensive and continuous phase. This research was conducted in three primary public health care centres in Surabaya, East Java, Indonesia. The variables were proactive coping that was measured by Proactive Coping Inventory (PCI) and self-care management that was measured by the Selfcare Management questionnaire. The data was analysed using a Spearman test. Results: This study showed that proactive coping had a positive correlation with self-care management in patients with pulmonary tuberculosis $(\mathrm{p}=0.000 ; \mathrm{r}=0,848)$. Conclusion: This study shows a strong correlation between the variables, where the higher the level of proactive coping, the better the self-care management in pulmonary tuberculosis patients. Further research can find out the factors that influence proactive coping in pulmonary tuberculosis patients, which can thus improve the self-care behaviour.
\end{abstract}

Keywords: coping proactive, self-care management, pulmonary tuberculosis

\section{INTRODUCTION}

Tuberculosis (TB) is a contagious bacterial infectious disease which has become a global concern. This disease is a major public health problem in Indonesia although a government program of TB control has been carried out over the last few decades. Indonesia is included in 14 countries with the world's highest burden of tuberculosis, tuberculosis-HIV, and tuberculosis-MDR (Falzon, D. Floyd, K. Getahun, H. Kanchar, A. Mirzayev, F. Raviglione, M. Timimi, H. Weyer, K. Zignol, 2015). Many means to control tuberculosis have already been undertaken and the incidents and deaths from tuberculosis have declined, but the worldwide death toll from tuberculosis is still high at 1.8 million people in 2016 (WHO, 2017).

The tuberculosis epidemic is larger than previously estimated, according to the WHO in the 2016 Global Tuberculosis Report. There are 10.4 million new tuberculosis incidence cases worldwide in the 2015 statistical data, equivalent to 28,500 people worldwide exposed to tuberculosis every day. Indonesia is included in the 6 countries that account for $60 \%$ of new tuberculosis cases in the world. Indonesia ranks second in the world as the largest contributor to tuberculosis patients after India (WHO, 2017). In 2015, the Case Detection Rate (CDR) of pulmonary tuberculosis in Indonesia was recorded at 125 cases per 100,000 population and in the last statistical data in 2015, there were 324,539 cases of tuberculosis in Indonesia (Kemenkes RI, 2016).

Statistical data of tuberculosis cases between provinces in 2015, East Java Province was ranked at second place with 110 cases per 100,000 population or equal to 21,475 , and Surabaya contributed as the largest cases of pulmonary tuberculosis in East Java Province as many as 2,330 cases of pulmonary tuberculosis (Kemenkes RI, 2015). In 2016, the cases of pulmonary tuberculosis in Surabaya did not decrease. The number of cases of pulmonary tuberculosis reached 2,382. The highest tuberculosis cases were found in North Surabaya. In all three public health centres in North Surabaya, there were 143 cases of pulmonary tuberculosis in 2016 and in the first quarter of 2017.

During the treatment period of 6 months, there are not only the physical problems suffered in patients with pulmonary tuberculosis but they also face psychosocial problems and emotional changes due to the illness (Dwidiyanti, Noorratri and Margawati, 2017). The psychosocial problems that can occur in patients with pulmonary tuberculosis are feeling isolated by friends and relatives and difficulty continuing work, thus causing them to choose being more secluded (Williams \& Kaur, 2016). The occurrence of psychosocial problems in pulmonary 
tuberculosis patients will affect the coping strategy to be used on the patient itself, to allow them to be able to withstand the stressors of the disease (Yellappa et al., 2016). The proper and effective use of coping creates a balance by adjusting to the change or burden and this will create an improvement in the individual (Mubarak and Susanto, 2006).

There has been a wide range of recent research on social cognition, social interaction, stress and coping aimed at analysing the process by which individuals can anticipate or detect potential stresses that will occur and have preventive measures to reduce the adverse consequences that will occur. Such behaviour reflects one form of coping which is proactive coping (Vaculikova, 2016). Individuals with proactive coping will take advantage of social and non-social resources, have goals for the future, use positive emotional strategies, and prevent and modify potential future stresses. (Schwarzer \& Taubert, 2002). Proactive coping also positively correlates with social support and has a positive impact on individuals to improve their well-being (Greenglass and Fiksenbaum, 2009).

The handling of pulmonary tuberculosis requires the patient and family's active role as a support system to improve the patient's own health status (Kemenkes RI, 2016). The home health treatment or self-care management conducted by the patient will maintain or restore health, minimise disability from the illness and improve the patient's independence. If self-care management is not done optimally, then there will be a decrease in the patient's health status (Clark, 2008).

Proactive coping is also one of the coping methods that has a direct relationship with self-efficacy which is one of the basic components to perform self-care actions (Drummond Suzanne, 2014). Stanojević et al. (2014) also pointed out that proactive coping has a strong relationship with self-efficacy so as to improve self-care behaviour in patients with chronic diseases such as pulmonary tuberculosis. Therefore, it can be expected that there is a relationship between the use of this proactive coping strategy and the management of self-care actions in pulmonary tuberculosis patients which will result in an improvement in the patient's health status (Stanojević et al., 2014).
It is necessary for the nurse as a caregiver and health care provider to provide better nursing intervention by improving pulmonary tuberculosis patients' coping so that the pattern of pulmonary tuberculosis treatment will have more leverage. Thus, the authors are interested in examining the relationship between proactive coping strategies and self-care management in patients with pulmonary tuberculosis,

\section{MATERIALS AND METHODS}

This research study used the quantitative method with a cross-sectional approach. The sample of the respondents in this study was pulmonary tuberculosis patients who are undergoing treatment; as many as 105 respondents. This research was conducted from January to June 2017 in three primary public health care centres in Surabaya, East Java, Indonesia.

The data was collected using instrument tools in the form of a Proactive Coping Inventory (PCI) questionnaire and a self-care management list questionnaire in patients with pulmonary tuberculosis. The process of data analysis was using a Spearman rank correlation test with $\alpha \leq 0.05$.

This research had been approved by the Health Research Ethics Commission of the Faculty of Nursing, Universitas Airlangga, Surabaya, Indonesia on July $4^{\text {th }}, 2017$ with the certificate number of ethics 410-KEPK.

\section{RESULTS}

The majority of the respondents were male $(51 \%)$, aged $46-55$ years old $(40 \%)$ with their most recent education being at primary level $(47 \%)$. Most of them were self-employed or a trader with an income less than 1 million rupiahs (Table 1).

The distribution of a highly proactive coping sub-scale was mostly found on the subscale of instrumental support seeking followed by the emotional support scale. A total of 52 respondents had a high level on the instrumental support subscale (Table 2).

$40.5 \%$ of the pulmonary tuberculosis patients had never been isolated as evidenced by the majority of the respondents never having paid any attention to the ventilation adequacy within the home. As many as $40.2 \%$ of respondents had rarely undertaken preventive measures, especially in the case of 
hand washing, wearing masks and sputum disposal. The respondents still rarely do good nutrition management, where as many as $56.1 \%$ rarely consumed balanced nutrition in adequate proportions. A total of $47.9 \%$ of the respondents were good in terms of treatment, especially in taking drugs and routine checkups at the health services, but there were still many who rarely did any exercise (Table 3 ).

Table 1. Demographic Characteristics of the Respondents

\begin{tabular}{lcc}
\hline Characteristic & n & \% \\
\hline Age & 22 & 21 \\
$15-25$ y.o & 23 & 22 \\
$26-35$ y.o & 18 & 17 \\
$36-45$ y.o & 42 & 40 \\
$46-55$ y.o & & \\
Sex & 53 & 51 \\
Male & 52 & 49 \\
Female & & \\
Educational Background & 51 & 47 \\
Elementary School & 13 & 13 \\
Junior High School & 38 & 36 \\
Senior High School & 3 & 4 \\
University/ Diploma & & \\
Occupation & 48 & 46 \\
Entrepreneur/ Merchant & 22 & 21 \\
Private Company & 2 & 2 \\
Government Employees & 33 & 31 \\
Others (Unemployed) & & \\
Income & & \\
$\quad$ 1 million & 45 & 43 \\
1 million < x $<$ million & 8 & 8 \\
$\geq 2$ million & 19 & 18 \\
No Income & 33 & 31 \\
\hline
\end{tabular}

Table 2. Proactive coping subscale in pulmonary TB patients

\begin{tabular}{lccc}
\hline \multirow{2}{*}{ Subscale } & \multicolumn{3}{c}{ Frequency } \\
\cline { 2 - 4 } & High & Moderate & Low \\
\hline Proactive Coping Scale & 38 & 56 & 11 \\
Reflective Coping Scale & 40 & 50 & 15 \\
Preventive Coping Scale & 46 & 42 & 17 \\
Avoidance Coping Scale & 42 & 48 & 15 \\
Strategic Planning Scale & 47 & 44 & 14 \\
Instrument Support & 52 & 40 & 13 \\
Seeking Scale & & & \\
Emotional Support Scale & 51 & 41 & 13 \\
\hline
\end{tabular}

Table 3. Self care management in pulmonary TB patients

\begin{tabular}{lccc}
\hline \multirow{2}{*}{ Sub-variable } & \multicolumn{3}{c}{ Frequency (\%) } \\
\cline { 2 - 4 } & Often & Rarely & Never \\
\hline Isolation Action & 25,2 & 34,3 & 40,5 \\
Preventive Action & 39,6 & 40,2 & 20,2 \\
Nutrition Management & 30,8 & 56,1 & 13.1 \\
Medication \& Excercise & 47,9 & 29,9 & 22,2 \\
\hline
\end{tabular}

The results of the Spearman correlation test obtained a level of significance $\mathrm{p}=0.000$, thus accepting the hypothesis which means that there is a relationship between proactive coping with self-care management in pulmonary tuberculosis patients. The correlation coefficient $(r)$ showed a positive correlation $(r=0.848)$ which means that it had a high correlation. The direction of the relationship was positive, which indicates the higher the level of proactive coping then the higher the level of self-care management of the pulmonary tuberculosis patients.

\section{DISCUSSION}

Based on Table 2, it was found that 55 respondents had a moderate proactive coping rate and self-care management level, 31 respondents had a high proactive coping rate and high self-care management level. The results of this study indicate that there was a strong correlation between proactive coping with self-care management in pulmonary tuberculosis patients. This result is in line with the theory that proactive coping can improve self-care behaviour in patients with chronic diseases such as pulmonary tuberculosis (Stanojević et al., 2014).

Based on Table 3, the largest frequency at a high level was found in the instrumental support subscale. The instrumental support subscale is an individual's focus for getting information, advice from others, support search and assistance when the individual is facing a stressor (Vaculikova, 2016). According to Greenglass and Fiksenbaum (2009), instrumental support or social support is positively correlated with proactive coping so that it has a positive impact on the individual to improve their well-being. Govender and Mash (2009) also said that social support is one of the factors to improve treatment compliance evidenced by the existence of a positive relationship between social support and proactive coping.

An example of an instrumental support search activity is where the pulmonary tuberculosis patients need information, advice, and help from others when problems occur. A total of 52 respondents stated that support such as advice and the assistance of others is needed when the pulmonary tuberculosis patients are undergoing treatment. The family is one aspect of this instrumental support 
Table 4 . The result of analysis

\begin{tabular}{lccc}
\multirow{2}{*}{$\begin{array}{c}\text { Level of Proactive } \\
\text { Coping }\end{array}$} & \multicolumn{3}{c}{$\begin{array}{c}\text { Self-care management } \\
\text { level }\end{array}$} \\
\cline { 2 - 4 } & Good & Moderate & Bad \\
\hline Low & 6 & 5 & 0 \\
Moderate & 2 & 55 & 2 \\
High & 1 & 3 & 31 \\
\hline Spearman's Rho $\mathrm{p}=0,000 ; \mathrm{r}=0,848$ \\
\hline
\end{tabular}

quest. One example of family-provided assistance for pulmonary tuberculosis patients is accompaniment at the time of the ingestion of TB drugs.

According to Mufarokhah, Putra and Dewi (2016), the improvement of the level of coping and the intention of the selfmanagement program (self-management program) will change the individual's behaviour. Changes in individual behaviour are influenced by behaviour control. De Ridder et al. (2012) explained that high selfcontrol would shape the conductive behaviours to allow them to achieve a healthy life, so it is very profitable for the individual. Thoolen et al. (2007) explained that individuals with proactive coping will perform self-regulation actions which are processes in which people control and direct their actions in order to fulfil their goals. Ogden (2012) added that when a person has achieved their desired goal, it will increase self-efficacy that directly affects the individual self-care. Drummond Suzanne (2014) explained that self-efficacy is self-confidence and is one of the basic components to perform self-care nursing actions.

The results of this study are consistent with the results of a study by Weni (2014), which revealed that there is a significant association of proactive coping with Diabetes Self-Care Activities in elderly people with type 2 diabetes mellitus. Patients with high proactive coping rates will increase their selfcare rates. In addition, proactive coping is a major predictor factor for coping mechanisms in patients with lower limb amputations (Solgajová, Sollár and Vörösová, 2015).

Table 2 shows that most patients have moderate proactive coping rates. This suggests that most pulmonary tuberculosis patients use proactive coping in everyday life even at moderate levels. The level of self-care management is also the majority, at a moderate level. This is due to the level of awareness of patients with pulmonary TB being low related to preventive measures for the transmission of pulmonary tuberculosis infection. Pulmonary TB patients only use masks at the time of taking TB drugs at the primary health care facilities when they meet the nurse or another health officer, and they still often dispose sputum indiscriminately.

Individuals with proactive coping see future events as a challenge and opportunity, by identifying collecting and utilising required resources (Stanojević et al., 2014). Thus, someone with proactive coping will take any action to be able to solve the challenge. Based on the results of interviews and questionnaires, it was also found that the respondents thought that recovering from the pulmonary tuberculosis disease is a challenge by having to complete the treatment until they are completely healed and that they can go on to be as normally active as before. The respondents believe that taking regular and routine medication will cure the patients of the pulmonary tuberculosis disease.

\section{CONCLUSIONS}

It can be concluded that most of the pulmonary tuberculosis clients in the three public health care centres in Pegirian, Pulo Sawah, and Perak East had moderate proactive coping rates and self-care management. Proactive coping's highest point was found on the subscale of an individual's attempt to obtain information, advice, support, and assistance when the individual was facing a stressor. Moreover, the self-care highest points were obtained from the client's statement when taking anti-TB drugs and following the schedule of health check-ups routinely.

High proactive coping rates have an impact on the patient's self-care or self-care measures. This indicates that the higher proactive coping level of patients with pulmonary tuberculosis makes the level of self-care management also increase.

It is expected that there should be an effort to study the psychosocial aspects of pulmonary tuberculosis patients, one of which is the use of individual coping. Health education about self-care at home related to pulmonary tuberculosis should not only be done when it is the first visit of the patients to the health services, but it must be sustained, so that it will create an effective treatment for the patients. It is expected for nurses to be able to 
increase the level of awareness of patients related to the transmission of pulmonary $\mathrm{TB}$ infection.

For further research, it can be expected to analyse the factors that influence the level of proactive coping in improving health level through self-care or self-care management in pulmonary tuberculosis patients.

\section{REFERENCES}

Clark, M. J. D. (2008) Community health nursing: advocacy for population health. 5th ed. Upper Saddle River N.J.: Pearson Prentice Hall.

Drummond Suzanne (2014) Being Proactive About Proactive Coping: Exploring Future-Oriented Coping and Appraisal within a Transactional Framework| EQUELLA, Thesis (PhD Doctorate), Griffith University, Brisbane. doi: https://www120.secure.griffith.edu.au/ rch/items/a419f1d2-c301-4f2b-a166efc7da07094c/1/Drummond_2014_01 Abstract.pdf.

Dwidiyanti, M., Noorratri, E. D. and Margawati, A. (2017) 'Improving Self-Efficacy and Physical SelfReliance of Patients with Pulmonary Tuberculosis through Mindfulness', Nurse Media Journal of Nursing, 6(2), p. 81. doi: 10.14710/nmjn.v6i2.12585.

Falzon, D. Floyd, K. Getahun, H. Kanchar, A. Mirzayev, F. Raviglione, M. Timimi, H. Weyer, K. Zignol, M. (2015) Use of high burden country lists for TB by WHO in the post-2015 era, WHO press. $\quad$ doi: http://www.who.int/tb/publications/glo bal_report/high_tb_burdencountrylists 2016-2020.pdf.

Govender, S. and Mash, R. (2009) 'What are the reasons for patients not adhering to their anti-TB treatment in a South African district hospital?'

Greenglass, E. R. and Fiksenbaum, L. (2009) 'Proactive Coping, Positive Affect, and Well-Being', European Psychologist, 14(1), pp. 29-39. doi: 10.1027/1016-9040.14.1.29.

Kemenkes RI (2015) Kementerian Kesehatan Republik Indonesia. 24 Maret. Jakarta.

Kemenkes RI (2016) Kementerian Kesehatan
Republik Indonesia. 2017th edn. Jakarta: Kementrerian Kesehatan RI. 2017.

Mubarak, W. I. and Susanto, B. A. (2006) Buku ajar ilmu keperawatan komunitas 2: teori \&amp; aplikasi dalam praktik dengan pendekatan dan asuhan keperawatan komunitas, gerontik dan keluarga. 1st edn. Jakarta: Sagung Seto.

Mufarokhah, H. M., Putra, S. and Dewi, Y. (2016) 'Self Management Program Meningkatkan Koping, Niat dan Kepatuhan Berobat Pasien PJK Setelah Pemberian Self Management Program', Jurnal NERS, 11(1), p. 56. doi: 10.20473/jn.V11I12016.56-62.

Ogden, J. (2012) Health psychology. McGrawHill.

de Ridder, D. T. D. et al. (2012) 'Taking Stock of Self-Control', Personality and Social Psychology Review, 16(1), pp. 76-99. doi: $10.1177 / 1088868311418749$.

Schwarzer Ralf and Taubert Steffen (2002) 'Tenacious Goal Pursuits and Striving Toward Personal Growth: Proactive Coping', Freie Universität Berlin, pp. 19-35. doi: http://citeseerx.ist.psu.edu/viewdoc/do wnload?doi=10.1.1.533.5201\&rep=rep $1 \&$ type $=$ pdf.

Solgajová, A., Sollár, T. and Vörösová, G. (2015) 'Gender, age and proactive coping as predictors of coping in patients with limb amputation', Kontakt, 17(2), pp. e67-e72. doi: https://doi.org/10.1016/j.kontakt.2015. 01.005 .

Stanojević, D. et al. (2014) 'Proactive Coping as a Mediator Between Resources and Outcomes: A Structural Equations Modeling Analysis', Applied Research in Quality of Life. Springer Netherlands, 9(4), pp. 871-885. doi: 10.1007/s11482-013-9274-2.

Thoolen, B. et al. (2007) 'Beyond Good Intentions: the development and evaluation of a proactive selfmanagement course for patients recently diagnosed with Type 2 diabetes', Health Education Research, 23(1), pp. 53-61. doi: 10.1093/her/cyl160.

Vaculikova, J. (2016) 'Proactive Coping 
Behavior in Sample of University Students in Helping Professions'.

Weni, M. W. (2014) Hubungan Koping Proaktif dengan Diabetes Self Care Activities pada Lansia dengan Diabetes Melitus Tipe 2. Universitas Airlangga.

WHO (2017) 'Global tuberculosis report 2016', WHO. World Health Organization. Available at: http://www.who.int/tb/publications/glo bal_report/gtbr2016_executive_summ ary.pdf.

Williams Veena and Kaur Harbans (2016) 'The Psychosocial Problems Of
Pulmonary Tuberculosis PatientsUndergoing DOTS Therapy (Direct Observed Treatment ShortCourse Therapy) in Selected Areas of Jalandhar District, Punjab.', Page 1 IOSR Journal of Pharmacy and Biological Sciences (IOSRJPBS). Bunkasha, 1(1), pp. 44-49.

Yellappa, V. et al. (2016) 'Coping with tuberculosis and directly observed treatment: a qualitative study among patients from South India', $B M C$ Health Services Research. BioMed Central, 16(1), p. 283. doi: 10.1186/s12913-016-1545-9. 